Limnol. Rev. (2014) 14,2: 75-81

\title{
Factors affecting the distribution patterns of aquatic macrophytes
}

\author{
Naseer Ahmad Dar ${ }^{\star}$ Ashok Kumar Pandit, Bashir Ahmad Ganai \\ Department of Environmental Science, University of Kashmir, Srinagar-190006, India, \\ *e-mail: naseerpulwama@gmail.com (corresponding author)
}

\begin{abstract}
Aquatic macrophytes constitute important components of many freshwater ecosystems. The manifold role of aquatic macrophytes in freshwater habitats is closely linked to their distribution, which in turn depends on a myriad of factors. Foremost, among these are light, water temperature, water quality changes and nutrient enrichment, sediment composition and fluctuations in water levels. Light and temperature are of paramount importance in determining the distribution (with depth, season and latitude), thereby influencing productivity and species composition as well. Sediment compositions markedly affect the growth rates of macrophytes which in turn have a profound influence on the distribution of aquatic macrophytes. Water quality changes and nutrient enrichment can cause considerable variations in the species richness, composition, and density of aquatic vegetation. The reduction in water levels could bring drastic changes in the species composition and distribution of macrophytes. Factors associated with competition, herbivory, land use and land cover changes etc. also play an important role in shaping macrophyte distribution and community structure. In this review we examine both biotic and abiotic factors that influence the structural attributes like species composition, distribution, abundance and diversity of aquatic macrophytes.
\end{abstract}

Key words: Abiotic and biotic factors, aquatic macrophytes, competition, freshwater ecosystems, species composition

\section{Introduction}

Aquatic macrophytes are considered photosynthetic organisms of freshwater habitats, comprising vascular plants, aquatic bryophytes and macroalgae growing permanently or temporally in aquatic environments (Jones et al. 2010). They play an important role in the structure and functioning of freshwater ecosystems (Wetzel 2001; Hrivnak et al. 2009; Tamire and Mengistou 2012). The macrophytes serve as a base of aquatic food-chains, besides they also actively contribute to the promotion and maintenance of food webs and services in freshwater ecosystems (Scheffer and Jeppesen 2007; Smith 2011). Aquatic macrophytes also act as important bioindicators of environmental conditions and long-term ecological changes in water quality (Lacoul and Freedman, 2006; Solimini et al. 2006). The function of macrophytes in these ecosystems is related to their structural attributes like species composition, distribution, abundance and diversity which in turn relies on various environmental factors such as light, water temperature, substrate composition, disturbance, competitive interactions, herbivory, epiphyte loading, water levels, quality of the lake water and sediment nutrients (Kaul et al. 1978; Pandit 1984, 1992; Barko and Smart 1986; Duarte et al. 1986; Lodge 1991; Cronk and Fennessey 2001; Wetzel
2001; Capers 2003; Pankhurst 2005; Jaikumar et al. 2011; Siraj et al. 2011; Feldmann 2012; Tamire and Mengistou 2012). Apart from these, factors such as composition and properties of sediments also seem to have significant effect on the diversity and distribution of certain macrophytic species (Dawson and Szoszkiewicz 1999; Heegaard et al. 2001; Makela et al. 2004). Vegetative and clonal reproduction is considered to be the major mechanism for population growth and dispersal of macrophytes because sexual reproduction and genetic recombination are often subordinate strategies (Wetzel 2001). The efficient reproduction strategies and good dispersal capabilities are the two factors that help some aquatic macrophytes to become cosmopolitan in distribution and display high levels of polymorphism and phenotypic plasticity in response to variations of environmental factors. (Sculthorpe 1967; Barrat-Segretain 1996; Santamaria 2002).

In view of the significant role played by macrophytes in freshwater ecosystems, understanding and quantifying the environmental factors that influence the distribution patterns of macrophytes is indispensable for integrated management practices of these ecosystems. The present paper, therefore, attempts to document the historical review of the factors that significantly govern the distribution patterns of aquatic macrophytes in freshwater ecosystems. 
A brief overview of the factors that affect the distribution of macrophytes is given as under.

\section{Abiotic factors}

Light

The distribution pattern of macrophytes is largely controlled by water clarity and the amount of light that reaches the plant. A number of studies have found these to be the most significant factors governing the abundance, composition and distribution of macrophytes (Bini et al. 1999; Lougheed et al. 2001; Pandit 2002). It is well documented that the underwater light plays an important role in determining the depth distribution of different groups of aquatic macrophytes (Sculthorpe 1971; Chambers and Kalff 1985; Dale 1986; Chambers and Prepas 1988; Hrivnak et al. 2006). Water level is closely related to light transmission, with deeper water hindering the processes of scattering and absorption (Wetzel 1988; Sand-Jensen and Borum 1991). A number of reports indicate that certain species of aquatic macrophytes, mostly submerged ones, usually extend into the depths in order to maximize their absorption of the light and $\mathrm{CO}_{2}$ needed for photosynthesis; for example, $\mathrm{Hy}$ drilla sp. is very effective in elongating its shoots (Barko and Smart 1981; Maberly and Madsen 2002). Submerged macrophytes have also been reported to grow to a depth of two to three times the Secchi depth (Chambers and Kalff 1985). Sand-Jensen (1990) found that epiphyte shading plays significant role in determining the depth distribution of submerged aquatic macrophytes. Chambers and Kalff (1985) and Dennison et al. (1993) obtained a positive relationship between Secchi depth and rhizophytes. They found that this relationship is probably related to light availability-dependent habitat heterogeneity for submerged species. Certain studies indicate that the climatic difference associated with geographic latitude seems to have a strong influence on the relationship between water transparency and depth distribution of submerged plants (Duarte and Kalff 1987).

\section{Temperature}

In most aquatic systems, seasonal variations in photoperiod and incident solar radiation trigger corresponding changes in water temperature (Barko et al. 1986). It is generally known that light and temperature act together in affecting growth, morphology, photosynthesis, chlorophyll composition and reproduction of macrophytes (Sastroutomo 1980, 1981; Barko et al. 1982, 1986; Chambers 1982; Nekrasova et al. 2003; Ronzhina et al. 2004; Robledo and Freile-Pelegrin 2005). Although temperature within the thermal tolerance promotes growth and reproduction in aquatic plants, decrease in water temperature may be one of the factors that are responsible for depth-related reductions in the seasonal growth of macrophytes (Barko et al. 1986). It is believed that the temporal changes in distribution of certain species of macrophytes are mainly temperature-dri- ven (Heikkinen et al. 2009; Alahuhta 2011; Kors et al. 2012). The variations that occur in the species composition and distribution of certain species of aquatic macrophytes, mostly submerged ones due to thermal changes, indicate that temperature is as important as light in influencing competitive interactions among coexisting species (Anderson 1969; Allen and Gorham 1973; Barko et al. 1986). Recent studies have found that the increased nutrient concentrations, derived from diffuse pollution due to increased precipitation in future can hinder temperature driven distribution changes of macrophytes (Jylha et al. 2004; Rosset et al. 2010).

\section{Water quality and sediment related characteristics}

A lot of research has been done from time to time to evaluate the effects of water quality, sediment characteristics and geological formations on aquatic macrophyte distribution (Kaul 1971; Chambers 1987; Gopal 1987; Barko et al. 1991; Heegaard et al. 2001; Lougheed et al. 2001; Mir 2009; Birk and Willby 2010; Alahuhta 2011; Uedeme-Naa et al. 2011; Tamire and Mengistou 2012; Gecheva et al. 2013; Sossey-Alaoui and Rosillon 2013). Riis et al. (2000) while examining the relationship between environmental factors and aquatic plant composition in Danish streams found that alkalinity was the most important factor in predicting plant distribution. The factors associated with sediments such as high organic matter content, poor oxygen availability, nutrient limitation and granulometric composition are known to influence the distribution and diversity of aquatic macrophytes to a varied extent (Drew and Lynch 1980; Sikora and Keeney 1983; Lachavanne 1985; Barko and Smart 1986; James and Barko 1990; Barko et al. 1991; Sand-Jensen 1998; Armstrong et al. 1999; Boedeltje et al. 2001). A few studies have indicated that the growth of rooted aquatic plants is favoured over phytoplankton due to higher concentration of phosphorus in the sediments (Scheffer et al. 1993). The distribution of macrophytes in freshwater ecosystems also seems to be influenced by the nature of the geological formations and the degree and nature of the pressure exerted on these environments (Sossey-Alaoui and Rosillon 2013).

\section{Nutrient enrichment}

It has been well emphasized that the distribution and growth of aquatic macrophytes are associated with nutrient rich environments particularly nitrate and phosphate which have been noted to favour macrophytes growth (Frankouich et al. 2006). Several studies have established that the nutrient enrichment can cause significant changes in the density, species composition and richness of aquatic vegetation in lakes (Toivonen and Huttunen 1995; Findlay and Houlahan 1997; Bini et al. 1999; Magee et al. 1999; Lougheed et al. 2001; Rosset et al. 2010; Alahuhta 2011). There is a possibility that the elevated nutrient concentrations might hamper climate-driven distribution patterns of macrophytes (Rosset et al. 2010). Nutrient enrichment of waters due to clay soils probably resulted in a positive relationship between helophyte vegetation distribution and fi- 
ner grained soils and less acidic bedrocks. Clay soils can promote littoral overgrowth both at the lake and habitat levels in boreal catchments (Partanen et al. 2009). Recently, Shah and Reshi (2014) linked the distribution of alien aquatic flora in different aquatic ecosystems of Kashmir Himalaya to their trophic status.

\section{Hydrological variations}

It has been established that the hydrologic and hydrodynamic conditions affect the distribution patterns of macrophytes mainly in two ways: (i) by the fluctuating water level (Makin et al. 1976; Spence 1982; Coops et al. 1996; Schwarz and Hawes 1997; Fernández-Aláez et al. 1999; Kors et al. 2012), and (ii) by mechanical stress caused by waves and water flow (Spence 1982; Idestam-Almquist and Kautsky 1995; Rea et al. 1998). Several studies have found that the variations in water depth lead to variations in species zonation, distribution, biomass and richness (Khedr and El-Demerdash 1997; Fernandez-Alaez 1999; Arts 2002; Lacoul and Freedman 2006). The turbidity of water also seems to determine the extent of colonization of submerged aquatic plants (Kaul et al. 1978; Kaul 1982; Pandit 1992, 2008; Scheffer et al. 1992). Nurminen (2003) noted that higher turbidity, fluctuations in water level and other factors seem to limit the macrophyte distribution to mainly turbidity tolerant species (e.g., Nymphaea, Nelumbo and emergents). Low water levels may have a greater impact on the submerged vegetation in comparison to the lower lakes, due to the steeper shorelines (Pankhurst 2005). It is believed that the reduction in water level and change in limnology of lake waters could change considerably the composition of macrophytes over decades (Deribessa 2006; Beneberu and Mengistou 2010). Kumar and Pandit (2008) while studying the effect of water level fluctuations on distribution of emergent vegetation in Hokersar wetland (Kashmir) maintained that water depth plays an important role in the presence, distribution and diversity of the emergent species. Day et al. (1988), however, found that water depth, the effects of spring flooding in removing litter and the fertility gradient produced by flowing water are the three main factors affecting vegetation composition.

\section{Exposure to wind and waves}

A number of studies have indicated that the exposure to wind and waves largely influences the distribution of aquatic plants in shallow waters (Chambers 1987; Vermaat and De Bruyne 1993; Pankhurst 2005). Hudon et al. (2000) found the biomass and distribution of submerged macrophytes to be influenced by site exposure and differences in species distribution attributable to growth form. Sand-Jensen (1989) held decrease in water depth responsible for increase in the wave-induced turbulent forces on the bottom. Spence (1982) found that the helophyte zone and especially the zone of floating-leaved plants decrease with the increasing lake area due to wind stress related to the height and strength of waves. He also obtained positive relationship between the lake area and helophytes in small and middle sized lake surfaces. A few studies have indicated that this relationship probably originates from habitat heterogeneity - as larger lakes encompass more microhabitats more species are able to find a suitable habitat with increasing area (Rorslett 1991; Jones et al. 2003; Heegaard 2004; Capers et al. 2010).

\section{Biotic factors}

Many authors have reported that the competitive interactions among plants, herbivory by invertebrates and vertebrates etc. are the major biological factors that shape aquatic vegetation composition and distribution in freshwater ecosystems (Chambers and Prepas 1990; Connors et al. 2000). Several studies have found that competitive interactions between naturally occurring species may play a larger role in shaping macrophyte distribution and community structure (Chambers and Prepas 1990; Pankhurst 2005; Hrivnak et al. 2009; Kors et al. 2012). There is some evidence that certain biotic factors such as grazers, pathogens etc. also influence the distribution patterns of submerged macrophytes (Nichols and Shaw 1983). It has been long believed that the introduction of exotic species by humans (e.g., Orconectes rusticus and Myriophyllum spicatum) can significantly reduce the population of native freshwater macrophytes (Lodge and Lorman 1987; Boylen et al. 1999; Wilson 2002).

\section{Other factors}

Apart from these, factors such as latitudinal and altitudinal pattern, dispersal, soil, bedrock and land cover and land use (LCLU) are also known to play an important role in macrophytes distribution and richness between lake catchments (Sand-Jensen et al. 2000; Jones et al. 2003; Heegaard 2004; Lacoul 2004; Edvardsen and Okland 2006; Lacoul and Freedman 2006; Chambers et al. 2008; Partanen et al. 2009; Capers et al. 2010; Alahuhta 2011). Certain studies have reported that the land use patterns generally have a strong influence on the distribution of macrophytes at finer extents (Luoto et al. 2007; Heino and Toivonen 2008; Alahuhta 2011). Lambert (2007) maintained that the distribution of charophytes is significantly affected by substratum type and topology (slope inclination of littorals and lake edges).

\section{Conclusion}

It is now evident that biotic as well as abiotic factors lead to considerable variations in distribution, diversity and abundance of aquatic macrophytes in freshwater ecosystems. The availability of light and temperature appears to be the most important factors in determining the macrophyte distribution (with depth, season and latitude), there- 
by influencing productivity as well as species composition of submerged macrophytes.

However, it is not easy to discriminate between the effects of these environmental variables on overall distribution patterns of aquatic macrophytes. Therefore, future research should focus on the influence of potential environmental variables (anthropogenic pressures, climatic change through human development and global warming) leading to change in the community structure and productivity of macrophytes. Moreover, emphasis should be given to the impact of eutrophication on distribution, diversity and density as well as productivity of macrophytes-making an important component of aquatic ecosystem.

\section{Acknowledgments}

We are thankful to Research Scholars Aquatic Ecology Laboratory, Department of Environmental Science and Centre of Research for Development, University of Kashmir, India for their valuable comments.

\section{References}

Alahuhta J., 2011, Patterns of aquatic macrophytes in the boreal region: Implications for spatial scale issues and ecological assessment [Dissertation], Acta. Univ. Oul. A 577: 1-66.

Allen E.D., Gorham R.R., 1973, Changes in the submerged macrophytes communities of Lake Wabamum as a result of thermal discharge, [in:] Reinelt E.R., Laycock A.H., Schultz W.M. (eds), Proc. Symp. Lakes of Western Canada, University of Alberta, Edmonton: 313-324.

Anderson R.R., 1969, Temperarure and rooted aquatic plants, Chesapeake Sci.10: 157-164.

Armstrong J., Afreen-Zobayed F., Blyth S., Armstrong W., 1999, Phragmites australis: Effects and survival and radial oxygen loss from roots, Aquat. Bot. 64(3-4): 275-289.

Arts G.H.P., 2002, Deterioration of Atlantic soft water macrophyte communities by acidification, eutrophication and alkalinisation, Aquat. Bot. 73: 373-393.

Barko J.W., Smart R.M., 1981, Comparative influences of light and temperature on the growth and metabolism of selected submersed freshwater macrophytes, Ecol. Monogr. 51: 219-236.

Barko J.W., Smart R.N., 1986, Sediment related mechanism of growth limitation in submerged macrophytes, Ecology 67: 1328-1340.

Barko J.W., Adams M.S., Clesceri N.L., 1986, Environmental factors and their consideration in the management of submerged aquatic vegetation: A review, J. Aquat. Plant Manage. 24: 1-10.

Barko J.W., Gunnison D., Carpenter S.R., 1991, Sediment interactions with aquatic macrophytes in freshwater, $\mathrm{Hy}$ drobiologia 595: 9-26.

Barko J.W., Hardin D.G., Mathews M.S., 1982, Growth and morphology of submersed freshwater macrophytes in relation to light and temperature, Can. J. Botany 60: 877887.

Barrat-Segretain M.H., 1996, Strategies of reproduction, dispersion, and competition in river plants: A review, Vegetatio 123:13-37.

Beneberu G., Mengistou S., 2010, Oligo trophication trend in Lake Ziway, Ethiopia, SINET Ethiop. J. Sci. 32: 141148.

Bini L.M., Thomaz S.M., Murphy K.J., Camargo A.F.M., 1999, Aquatic macrophyte distribution in relation to water and sediment conditions in the Itaipu Reservoir, Brazil, Hydrobiologia 415: 147-154.

Birk S., Willby N., 2010, Towards harmonization of ecological quality classification: establishing common grounds in European macrophyte assessment for rivers, Hydrobiologia 652: 149-163.

Boedeltje G., Smolders A.J.P., Roelofs J.G.M., Groenendael J.M.V., 2001, Constructed shallow zonesalong navigation canals: vegetation establishment and hange in relation to environmental characteristics, Aquat. Conserv. Mar. Freshw. Ecosyst. 11: 453-0471.

Boylen C.W., Eichler L.W., Madsen J.D., 1999, Loss of native aquatic plant species in a community dominated by Eurasian watermilfoil, Hydrobiologia 415: 207-211.

Capers R.S., 2003, Macrophyte colonization in a freshwater tidal wetland. Lyme, CT, USA, Aquat. Bot. 77: 325-338.

Capers R.S., Selsky R., Bugbee G.J., 2010, The relative importance of local conditions and regional processes in structuring aquatic plant communities, Freshwater Biol. 55: 952-966.

Chambers P.A., 1982, Light, temperature and the induction of dormancy in Potamogeton crispus and Potamogeton obtusifolius [Unpublished Ph.D. Thesis], University of St. Andrews.

Chambers P.A., 1987, Nearshore occurrence of submersed aquatic macrophytes in relation to wave action, Can. J. Fish. Aquat. Sci. 44: 1666-1669.

Chambers P.A., Kalff J., 1985, Depth distribution and biomass of submerged aquatic macrophyte communities in relation to Secchi depth, Can. J. Fish. Aquat. Sci. 42: 701-709.

Chambers P.A., Prepas E.E., 1988, Underwater spectral attenuation and its effect on the maximum depth of angiosperm colonization, Can. J. Fish. Aquat. Sci. 45: 10101017.

Chambers P.A., Prepas E.E., 1990, Competition and coexistence in submerged aquatic plant communities: the effects of species interactions versus abiotic factors, Freshwater Biol. 23: 541-550.

Chambers P.A., Lacoul P., Murphy K.J., Thomaz S.M., 2008, Global diversity of aquatic macrophytes in freshwater, Hydrobiologia 595: 9-26.

Connors L.M., Kiviat E., Groffman P.M., Ostfeld R., 2000, Muskrat (Ondatra zibethicus) disturbance to vegetation and potential net nitrogen mineralization and nitrification rates in a freshwater tidal marsh, Am. Midl. Nat. 143: 53-63. 
Coops H., Brink F.W.B., Velde V.G., 1996, Growth and morphological responses of four helophyte species in an experimental water-depht gradient, Aquat. Bot. 54: 11-24.

Cronk J.K., Fennessy M.S., 2001, Wetland Plants: Biology and Ecology, Lewis Publ., Boca Raton, pp. 462.

Dale H.M., 1986, Temperature and light: the determining factor in maximum depth distribution of aquatic macrophytes in Ontario,Canada, Hydrobiologia 133: 73-77.

Dawson F.H., Szoszkiewicz K., 1999, Relationships of some ecological factors with the associations of vegetation in British rivers, Hydrobiologia 415: 117-122.

Day R.T., Keddy P.A., McNeill J., Carleton T., 1988, Fertility and disturbance gradients: a summary model for riverine marsh vegetation, Ecology 69: 1044-1054.

Dennison W.C., Orth R.J., Moore K.A., Stevenson J.C., Carter V., Kollar S., Bergstrom P.W., Batiuk R.A., 1993, Assessing water with submersed aquatic vegetation, BioSience 143: 86-94.

Deribessa A., 2006, Groundwater and Surface Water Interaction and Geoenvironmental Changes in the Ziway Catchment [Unpublished M.Sc. Thesis], Addis Ababa University, Addis Ababa.

Drew M. C., Lynch J. M., 1980, Soil anaerobiosis, microorganisms, and root function, Annu. Rev. Phytopathol. 18: 37-66.

Duarte C.M., Kalff, J., Peters R.H., 1986, Pattern in biomass and cover of aquatic macrophytes in lakes, Can. J. Fish. Aquat. Sci. 43: 1900-1908.

Duarte C. M., Kalff J., 1987, Weight-density relationship in submerged macrophytes. The importance of light and plant geometry, Oecologia 72: 612-617.

Edvardsen A., Okland R.H., 2006, Variation in plant species composition in and adjacent to 64 Ponds in SE Norwegian agricultural landscapes, Aquat. Bot. 85: 92-102.

Feldmann T., 2012, The structuring role of lake conditions for aquatic macrophytes [Ph.D. Thesis], Estonian University of Life Sciences, Tartu, pp. 182.

Fernández-Aláez C., Fernández-Aláez M., Bécares E., 1999, Influence of water level fluctuation on the structure and composition of macrophyte vegetation in two small temporary lakes in the northwest of Spain, Hydrobiology 415: 155-162.

Findlay C.S., Houlahan J., 1997, Anthropogenic correlates of species richness in southeastern Ontario wetlands, Conserv. Biol. 11: 1000-1009.

Frankouich T.A., Gainer E.E., Zieman J.C., Wachnick A.H., 2006, Spatial and temporal distribution of epiphytic diatoms growing on Thalassic testudinum Banks ex Konigh. Relationship to waters quality, Hydrobiology 560: 259271.

Gecheva G., Yurukova L., Cheshmedjiev S., 2013, Patterns of aquatic macrophyte species composition and distribution in Bulgarian rivers, Turk. J. Bot. 37: 99-110.

Gopal B., 1987, Water Hyacinth: Biology, Ecology and Management, Elsevier, Amsterdam, p 471.

Heegaard E., 2004, Trends in aquatic macrophyte species turnover in Northern Ireland - which factors determine the spatial distribution of local species turnover? Global Ecol. Biogeogr. 13(5): 397-408.

Heegaard E., Birks H.H., Gibson C.E., Smith S.J., WolfeMurphy S., 2001, Species-environmental relationships of aquatic macrophytes in Northern Ireland, Aquat. Bot. 70: 175-223.

Heikkinen R.K., Leikola N., Fronzek S., Lampinen R., Toivonen H., 2009, Predicting distribution patterns and recent northward range shift of an invasive aquatic plant: Elodea canadensis in Europe, BioRisk 2: 1-32.

Heino J., Toivonen H., 2008, Aquatic plant biodiversity at high latitudes: patterns of richness and rarity in Finnish freshwater macrophytes, Boreal Env. Res. 13: 1-14.

Hrivnak R., Otahelova H., Jarolimek I., 2006, Diversity of aquatic macrophytes in relation to environmental factors in the Slatina river (Slovakia), Biologia 61: 156-168.

Hrivnak R., Otahelova H., Valachovic M., 2009, Macrophyte distribution and ecological status of the Turiec river (Slovakia): changes after seven years. Arch. Biol. Sci., Belgrade 61(2): 297-306.

Hudon C., Lalonde S., Gagnon P., 2000, Ranking the effects of site exposure, plant growth form, water depth, and transparency on aquatic plant biomass, Can. J. Fish. Aquat. Sci., 57(Suppl. 1): 31-42.

Idestam-Almquist J., Kautsky L., 1995, Plastic responses in morphology of Potamogeton pectinatus L. to sediment and abovesediment conditions at two sites in the northern Baltic proper, Aquat. Bot. 52: 205-216.

Jaikumar M., Chellaiyan D., Kanagu L., Kumar P.S., Stella C., 2011, Distribution and succession of aquatic macrophytes in Chilka Lake, Indian J. Evol. Nat. Environ. 3(16): 499-508.

James W.F., Barko J.W., 1990, Macrophyte influences on the zonation of sediment accretion and composition in a north-temperate reservoir, Arch. Hydrobiol. 2: 129-142.

Jones J.I., Li W., Maberly S.C., 2003, Area, altitude and aquatic plant diversity, Ecography 26: 411-420.

Jones J.L., Colins A.L., Nada P.S., Sear D.A., 2010, The relationship between fire sediment and macrophytes in $\mathrm{Ri}$ vers, River Res. Appl. 20: 111-125.

Jylha K., Tuomenvirta H., Ruosteenoja K., 2004, Climate change projections for Finland during 21st century, Boreal Env. Res. 9: 127-152.

Kaul S., 1982, Community architecture, biomass and production in some typical wetlands of Kashmir, Indian J. Ecol. 9: 320-329.

Kaul V., 1971, Production and ecology of some macrophytes of Kashmir lakes, Hydrobiolgia 12: 63-69.

Kaul V., Tristal C.L., Handoo J.K., 1978, Distribution and production of macrophytes in some aquatic bodies of Kashmir, [in:] Singh J.S., Gopal B. (eds), Glimpses of Ecology, Prakash Publishers, Jaipur: 313-334.

Khedr A.H., El-Demerdash M.A., 1997, Distribution of aquatic plants in relation to environmental factors in the Nile Delta, Aquat. Bot. 56: 75-86.

Kors A., Vilbaste S., Kairo K., Pall P., Piirsoo K., Truu J., Viik M., 2012, Temporal changes in the composition of ma- 
crophytes communities and environmental factors governing the distribution of aquatic plants in an unregulated lowland river, Emajogi, Estonia, Boreal Env. Res. 17: 460-472.

Kumar R., Pandit A. K., 2008, Effect of water level fluctuations on distribution of emergent vegetation in Hokerser wetland, Kashmir, Proc. Nat. Acad. Sci. India, Sect B, 78: 227-233.

Lachavanne J.B., 1985, The influence of accelerated eutrophication on the macrophytes of Swiss lakes: Abundance and distribution. Verh. Internat. Verein. Limnol. 22: 2950-2955.

Lacoul P., 2004, Aquatic macrophyte distribution in response to physical and chemical environment of the lakes along an altitudinal gradient in the Himalayas, Nepal [Ph.D. Thesis], Dalhousie University, Halifax.

Lacoul P., Freedman B., 2006, Environmental influences on aquatic plants in freshwater ecosystems, Environ. Rev. 14: 89-136.

Lambert S.J, 2007, The environmental range and tolerance limits of British stoneworts Charophytes [PhD Thesis], University of East Anglia, Norwich.

Lodge D.M., 1991, Herbivory on freshwater macrophytes, Aquat. Bot. 41: 195-224.

Lodge D.M., Lorman J.G., 1987, Reductions in submersed macrophytes biomass and species richness by the crayfish Orconectes rusticus, Can. J. Fish. Aquat. Sci. 44: 591597.

Lougheed V.L., Crosbie B., Chow-Fraser P., 2001, Primary determinants of macrophyte community structure in 62 marshes across the Great Lakes basin: latitude, land use, and water quality effects, Can. J. Fish. Aquat. Sci. 58: 1603-1612.

Luoto M., Virkkala R., Heikkinen R.K., 2007, The role of land cover in bioclimatic models depends on spatial resolution, Global Ecol. Biogeogr. 16(1): 34-42.

Maberly S.C., Madsen T.V., 2002, Freshwater angiosperm carbon concentrating mechanisms: processes and patterns, Func. Plant Biol. 29: 393-405.

Magee T.K., Ernst T.L., Kentula M.E., Dwire K.A., 1999, Floristic comparison of freshwater wetlands in an urbanizing environment, Wetlands 19: 477-489.

Makela S., Huitu E., Arvola L., 2004, Spatial patterns in aquatic vegetation composition and environmental covariates along chains of lakes in the Kokemäenjoki watershed, S. Finland, Aquat. Bot. 80: 253-269.

Makin M.J., Kingham T.J., Waddams A.E., Birchall C.J., Eavis B.W., 1976, Prospects for irrigation development around Lake Ziway, Ethiopia, Land Res. Study Division, UK Ministry of Overseas Development, Report 26, Tolworth.

Mir A.A., 2009, Composition and distribution of macrophytes in Hokersar - A wetland of international importance in Kashmir Himalaya, Int. J. Climate Change: Impacts and Responses 1(4): 23-35.

Nekrasova G.F., Ronzhina D.A., Maleva M.G., P'yankov V.I., 2003, Photosynthetic Metabolism and Activity of Carboxylating Enzymes in Emergent, Floating, and Sub- merged Leaves of Hydrophytes, Russ. J. Plant Physiol. 50: 57-67.

Nichols S.A., Shaw B.H., 1983, Physical, chemical and biological contril of aquatic macrophytes. Lake Restoration, Protection and Management, Proc.2nd Ann. Conf. N. Amer. Lk. Manage. Soc., Oct. 1982, Vancouver, EPA 404/5-83-001.U.S., EPA, Washington: 181-192.

Nurminen L., 2003, Macrophyte species composition reflecting water quality changes in adjacent water bodies of Lake Hiidenvesi, Finland, Ann. Bot. Fenn. 40: 199-208.

Pandit A.K., 1984, Role of macrophytes in the aquatic ecosystems and management of freshwater resources, J. Environ. Manage. 18: 73-78.

Pandit A.K., 1992, Macrophytes as component of Dal Lake Ecosystem, [in:] Mishra R., Saksena D.N. (eds), Aquatic Ecology, Ashish Publ. House, New Delhi: 45-67.

Pandit A.K., 2002, Freshwater biological resources of Kashmir Himalaya, [in:] Pandit A.K. (ed.), Natural Resources of Western Himalaya, Valley Book House, Srinagar: 123-174.

Pandit A.K., 2008, Biodiversity of wetlands in Kashmir Himalaya, Proc. Nat. Acad. Sci. 78: 29-51.

Pankhurst H., 2005, Patterns in the Distribution of Aquatic Macrophytes in Georgian Bay, Ontario, Final Report for Senior Honours Project Submitted to: Department of BiologyMcMaster University 1280 Main Street West. Hamilton, ON L8S 4K1.

Partanen S., Luoto M., Hellsten S., 2009, Habitat level determinants of emergent macrophytes occurrence, extension and change in two large boreal lakes in Finland, Aquat. Bot. 90: 261-268.

Rea T.E., Karapatakis D.J., Guy K.K., Pinder III J.E., Mackey Jr. H.E., 1998, The relative effects of water depth, fetch and other physical factors on the development of macrophytes in small southeastern US pond, Aquat. Bot. 61: 289-299.

Riis T., Sand-Jensen K., Vestergaard O., 2000, Plant communities in lowland Danish streams: species composition and environmental factors, Aquat. Bot. 66: 255-272.

Robledo D., Freile-Pelegrin Y., 2005, Seasonal variation in photosynthesis and biochemical composition of Caulerpa spp. Bryopsidales, Chlorophyta) from the Gulf of Mexico, Phycologia 44: 312-319.

Ronzhina D.A., Nekrasova G.F., P’yankov V.I., 2004, Comparative Characterization of the Pigment Complex in Emergent, Floating, and Submerged Leaves of Hydrophytes, Russ. J. Plant Physiol. 51: 21-27.

Rorslett B., 1991, Principal determinants of aquatic macrophyte richness in northern European lakes, Aquat. Bot. 39: 173-193.

Rosset V., Lehmann A., Oertli B., 2010, Warmer and richer? Predicting the impact of climate warming on species richness in small temperate waterbodies, Glob. Change Biol. 16: 2376-2387.

Sand-Jensen K., 1989, Environmental variables and their effect on photosynthesis of aquatic plant communities, Aquat. Bot. 34: 5-26. 
Sand-Jensen K., 1990, Epiphyte shading - its role in resulting depth distribution of submerged aquatic macrophytes, Folia Geobot. Phytotax. 25: 315-320.

Sand-Jensen K., 1998, Influence of submerged macrophytes on sediments composition and near-bed flow in lowland streams, Freshwater Biol. 39: 663-679.

Sand-Jensen K., Borum J., 1991, Interactions among phytoplankton, periphyton, and macrophytes in temperate freshwaters and estuaries, Aquat. Bot. 41: 137-176.

Sand-Jensen K., Riis T., Vestergaard O., Larsen S.E., 2000, Macrophyte decline in Danish lakes and streams over the past 100 years, J. Ecol. 88: 1030-1040.

Santamaria L., 2002, Why are most aquatic plants widely distributed? Dispersal, clonal growth and small-scale heterogeneity in a stressful environment, Acta Oecologica 23: 137-154.

Sastroutomo S.S., 1980, Environmental control of turion formation in curly pondweed, Potamogeton crispus L., Physiol. Plant. 49: 261-264.

Sastroutomo S.S., 1981, Turion formation, dormancy and germination of curly pondweed, Potamogeton crispus L., Aquat. Bot. 10: 161-173.

Scheffer M., De Redelijkheid M.R., Noppert F., 1992, Distribution and dynamics of submerged vegetation in a chain of shallow Eutrophic lakes, Aquat. Bot, 42: 199-216.

Scheffer M., Hosper S.H., Meijer M.L., Moss B., 1993, Alternative equilibria in shallow lakes, Trends Ecol. Evol. 8: 275-279.

Scheffer M., Jeppesen E., 2007, Regime shifts in shallow lakes, Ecosystems 10: 1-3.

Schwarz A.M., Hawes I., 1997, Effects of changing water clarity on characean biomass and species composition in a large oligotroophic lake, Aquat. Bot. 56: 169-181.

Sculthorpe C.D., 1967, The Biology of Aquatic Vascular Plants, Edward Arnold Ltd., London, pp. 610.

Sculthorpe C.D., 1971, The Biology of Aquatic Vascular Plants, Edward Arnold Ltd., London, pp. 601.

Shah M.A., Reshi Z.A., 2014, Characterization of alien aquatic flora of Kashmir Himalaya: implications for invasion management, Trop. Ecol. 55(2):143-157.

Sikora L.J., Keeney D.R., 1983, Further aspects of soil chemistry under anaerobic conditions, [in:] Gore A.J.P. (ed.), Mires: swamp, bog, fen, and moor, Elsevier, Amsterdam: 247-256.

Siraj S., Yousuf A.R., Parveen M., 2011, Spatio-temporal dynamics of macrophytes in relation to ecology of a Kashmir Himalayan Wetland, Int. Res. J. Biochem. Bioinformatics 1(4): 84-88.

Smith J.E., 2011, Algae, [in:] Simberloff D., Rejmanek M. (eds) Encyclopedia of biological invasions, University of California Press, Los Angeles: 11-15.

Solimini A.G., Cardoso A.C., Heiskanen A., 2006, Indicators and Method for Ecological Status Assessment under Water Framework Development, European Commission: Joint Reseach Center, EUR22314EN, Luxemburg.

Sossey-Alaoui K., Rosillon F., 2013, Macrophytic Distribution and Trophic State of Some Natural and Impacted Watercourses - Belgium Wallonia, Int. J. Water Sci. 2(2): $1-11$.

Spence D.H.N., 1982, The zonation of plants in freshwater lakes, Adv. Ecol. Res. 12: 37-125.

Tamire G., Mengistou S., 2012, Macrophyte species composition, distribution and diversity in relation to some physicochemical factors in the littoral zone of Lake Ziway, Ethiopia, Afr. J. Ecol. 51: 66-77.

Toivonen H., Huttunen P., 1995, Aquatic macrophytes and ecological gradients in 57 small lakes in southern Finland, Aquat. Bot. 51: 197-221.

Uedeme-Naa B., Gabriel U.U., Akinrotim O.A., 2011, The relationship between aquatic macrophytes and water quality in Nta-wogba stream, Port Harcourt, Nigeria, Cont. J. Fisheries Aquat. Sci. 5(2): 6-16.

Vermaat J.E., De Bruyne R.J., 1993, Factors limiting the distribution of submerged waterplants in the lowland River Vecht .The Netherlands, Freshwater Biol. 30: 147-157.

Wetzel R., 1988, Water as an environment for plant life, [in:] Symoens J.J. (ed.), Vegetation of Inland Waters, Kluwer, Boston: 1-30.

Wetzel R.G., 2001, Limnology. Lake and river ecosystems, Academic Press, San Diego, pp. 1006.

Wilson K.A., 2002, Impacts of the Invasive Rusty Crayfish (Orconectes rusticus) in Northern Wisconsin Lakes Zoology, University of Wisconsin, Madison, pp.194. 